\title{
Efficacy and safety of sorafenib for advanced renal cell carcinoma: real-world data of patients with renal impairment
}

\author{
Katsunori Tatsugami ${ }^{1}$, Mototsugu Oya², Koki Kabu ${ }^{3}$ and Hideyuki Akaza ${ }^{4}$ \\ ${ }^{1}$ Department of Urology, Graduate School of Medical Science, Kyushu University, Higashi-ku, Fukuoka City 812-8582, Japan \\ ${ }^{2}$ Department of Urology, Keio University School of Medicine, Shinjuku-ku, Tokyo 160-8582, Japan \\ ${ }^{3}$ Medical Affairs Oncology and Hematology, Bayer Yakuhin, Ltd., Chiyoda-ku, Tokyo 100-8265, Japan \\ ${ }^{4}$ Department of Strategic Investigation on Comprehensive Cancer Network, Interfaculty Initiative in Information Studies/ \\ Graduate School of Interdisciplinary Information Studies, The University of Tokyo, Meguro-ku, Tokyo 153-8904, Japan \\ Correspondence to: Katsunori Tatsugami, email: ktatsu@uro.med.kyushu-u.ac.jp \\ Keywords: sorafenib; advanced RCC; eGFR; real-world data; propensity score matching \\ Received: January 12, $2018 \quad$ Accepted: February 23, $2018 \quad$ Published: April 10, 2018 \\ Copyright: Tatsugami et al. This is an open-access article distributed under the terms of the Creative Commons Attribution License \\ 3.0 (CC BY 3.0), which permits unrestricted use, distribution, and reproduction in any medium, provided the original author and \\ source are credited.
}

\section{ABSTRACT}

Background: We retrospectively analysed the efficacy and safety of sorafenib in patients with advanced renal cell carcinoma with renal impairment.

Methods: Patients were divided into two groups by an estimated glomerular filtration rate (eGFR) cut-off of $45 \mathrm{~mL} / \mathrm{min} / 1.73 \mathrm{~m}^{2}$. Background factors considered to affect prognosis were well balanced by propensity score matching between the groups. Demographics, dose modification, adverse events, tumour response, progression-free survival, and renal function (eGFR) were evaluated.

Results: Among 935 and 2008 patients with an eGFR of $<45$ and $\geq 45$, respectively, 613 pairs were matched. The mean starting dose was significantly lower in patients with an eGFR of <45; however, the mean daily dose, median treatment duration, progression-free survival, and tumour response were similar between the groups. In terms of safety, no significant differences were found in serious adverse events, although cytopaenia ( $16.6 \%$ vs $10.6 \%)$ and renal dysfunction $(4.4 \%$ vs $0.7 \%)$ were higher in patients with an eGFR of $<45$ than $\geq 45$ in all adverse events. There were also no differences in dose modification, including dose reduction, dose interruption, and treatment discontinuation.

Conclusion: Throughout the 12-month observation period, sorafenib in patients with an eGFR of $<\mathbf{4 5}$ and $\geq \mathbf{4 5}$ showed similar safety and efficacy, and treatment was continued without affecting renal function.

\section{INTRODUCTION}

Sorafenib, a vascular endothelial growth factor receptor-tyrosine kinase inhibitor (VEGFR-TKI), was approved as a first-in-class molecular-targeted drug for patients with unresectable and recurrent renal cell carcinoma (RCC) due to the extension of progression-free survival (PFS) in a phase 3 study [1]. VEGFR is highly expressed on vascular endothelial cells and glomerular epithelial cells (podocytes). This receptor regulates the formation of fenestrations and slit diaphragms in vascular endothelial cells and podocytes, respectively, and blockade of VEGFR signal transduction leads to proteinuria [2, 3]. Therefore, although tumour shrinkage is expected in patients with RCC treated with VEGFR-TKIs, there is concern that such treatment may induce a decrease in renal function. Because a limited number of reports have described the relationship between VEGFR-TKIs and renal function in patients with RCC, studies on the safety and efficacy of VEGFR-TKIs for patients with RCC exhibiting low renal function are needed. 
The kidney is a multifunctional organ that plays an important role in maintaining bodily homeostasis by excreting body wastes, regulating haematopoiesis, and balancing the electrolytes in the body. Chronic kidney disease (CKD) is generally defined by the estimated glomerular filtration rate (eGFR), an index of renal function, and is considered to be present when the eGFR is $<60 \mathrm{~mL} / \mathrm{min} / 1.73 \mathrm{~m}^{2}$ for $>3$ months. CKD increases the risk of end-stage renal disease and death due to cardiovascular disease (CVD) [4]. In particular, studies have shown that when the eGFR decreases to $<45 \mathrm{~mL} /$ $\min / 1.73 \mathrm{~m}^{2}$, the all-cause mortality, CVD events, and hospitalisation rates rapidly increase $[5,6]$. In the present study, we analysed the safety and efficacy of sorafenib in patients with advanced RCC with an eGFR of $<45 \mathrm{~mL} /$ $\mathrm{min} / 1.73 \mathrm{~m}^{2}$ (CKD stage $<\mathrm{G} 3 \mathrm{~b}$ ) using real-world data by propensity score matching.

\section{RESULTS}

\section{Patients' demographics according to eGFR}

Before matching, patients with an eGFR of $<45$ vs $\geq 45 \mathrm{~mL} / \mathrm{min} / 1.73 \mathrm{~m}^{2}$ showed significant differences in age (69.2 \pm 9.0 vs $63.9 \pm 10.8$ years, $P<0.0001)$, eGFR $\left(33.3 \pm 11.0\right.$ vs $\left.63.9 \pm 17.7 \mathrm{~mL} / \mathrm{min} / 1.73 \mathrm{~m}^{2}, P<0.0001\right)$, prior surgery $(85.7 \%$ vs $81.5 \%, P=0.0055)$, metastasis (bone) $(27.5 \%$ vs $33.7 \%, P=0.0008)$, and favourable/ intermediate/poor MSKCC risk (14.0/66.7/5.6\% vs $20.2 / 59.7 / 6.2 \%, P=0.0008)$. However, the patients' background factors were balanced after matching except for metastasis to the contralateral kidney $(9.0 \%$ vs $5.9 \%$, $P=0.0384)$ (Table 1).

\section{Treatment with sorafenib}

The mean starting dose of sorafenib was significantly lower in patients with an eGFR of $<45$ than $\geq 45 \mathrm{~mL} / \mathrm{min} / 1.73 \mathrm{~m}^{2}(687.1 \pm 192.1$ vs $726.3 \pm 159.8$ $\mathrm{mg} /$ day, $P=0.0001)$. However, there was no significant difference in the median [interquartile range] daily dose (484.4 [388.5] vs 481.0 [415.5] mg/day, $P=0.3181$ ), median duration of treatment (6.11 [10.22] vs 6.60 [9.72] months, $P=0.2944$ ), or dose modifications including dose reduction $(58.2 \%$ vs $58.7 \%, P=0.862)$, dose interruption (43.9\% vs $42.9 \%, P=0.7295)$, and treatment discontinuation (70.0\% vs 69.8\%, $P=0.9504)$ (Table 2). There was no difference in the numbers of patients who discontinued sorafenib treatment due to adverse events (AEs) or insufficient efficacy (Table 2).

\section{AEs}

No significant differences were found in serious AEs $(53.8 \%$ vs $50.9 \%, P=0.303)$; however, the total cytopaenia $(16.6 \%$ vs $10.6 \%, P=0.0021)$ and total renal failure/dysfunction $(4.4 \%$ vs $0.7 \%, P<0.0001)$ were significantly higher in patients with an eGFR of $<45$ than $\geq 45 \mathrm{~mL} / \mathrm{min} / 1.73 \mathrm{~m}^{2}$. Other AEs were similarly observed in both groups (Table 3 ).

\section{Tumour response}

The rates of complete response (CR), partial response (PR), and stable disease (SD) in patients with an eGFR of $<45 v s \geq 45 \mathrm{~mL} / \mathrm{min} / 1.73 \mathrm{~m}^{2}$ were $1.8 \% v s$ $3.0 \%, 24.3 \%$ vs $26.4 \%$, and $59.8 \%$ vs $57.7 \%$, respectively. The objective response rate (CR + PR) and disease control rate $(\mathrm{CR}+\mathrm{PR}+\mathrm{SD})$ in patients with an eGFR of $<45 v \mathrm{~s}$ $\geq 45 \mathrm{~mL} / \mathrm{min} / 1.73 \mathrm{~m}^{2}$ were $26.1 \%$ vs $29.4 \%(P=0.2132)$ and $85.8 \%$ vs $87.1 \%(P=0.5350)$, respectively. Overall, sorafenib treatment was associated with a similar tumour response rate in both groups (Table 4). Additionally, the median PFS in patients with an eGFR of $<45 v s \geq 45 \mathrm{~mL} /$ $\mathrm{min} / 1.73 \mathrm{~m}^{2}$ was 225 vs 253 days, respectively (hazard ratio, 1.077; 95\% confidence interval, 0.869-1.160), without a significant difference $(P=0.9225)$ (Figure 1).

\section{Influence on renal function}

Because a high incidence of sorafenib-induced renal failure/dysfunction was observed in patients with an eGFR of $<45 \mathrm{~mL} / \mathrm{min} / 1.73 \mathrm{~m}^{2}$, we analysed the impact of sorafenib on the change in renal function of patients with renal impairment between those with an eGFR of $<45$ and $\geq 45 \mathrm{~mL} / \mathrm{min} / 1.73 \mathrm{~m}^{2}$. The mean eGFR at baseline in patients with an eGFR of $<45$ vs $\geq 45 \mathrm{~mL} / \mathrm{min} / 1.73 \mathrm{~m}^{2}$ was 33.8 vs $55.9 \mathrm{~mL} / \mathrm{min} / 1.73 \mathrm{~m}^{2}$, and the renal function was retained throughout the 12-month observation period (Figure 2).

\section{DISCUSSION}

In previous clinical studies of TKI treatment in patients with advanced RCC, an increase in creatinine or proteinuria was sometimes observed; however, such increases do not necessarily reflect clinical practice involving patients with renal impairment. For instance, in the AXIS trial, creatinine increased by $55 \%$ and $41 \%$ in patients treated with axitinib and sorafenib, respectively [7], and proteinuria was observed in $10.7 \%$ and $6.6 \%$ [8] of all patients, respectively. However, the inclusion criterion for renal function in the AXIS trial was a creatinine level of $\leq 1.5 \mathrm{mg} / \mathrm{dL}$ or creatinine clearance rate of $\geq 60 \mathrm{~mL} / \mathrm{min}$ [8]; this information is not sufficient to evaluate the safety and AEs in patients with renal impairment. In one study in the clinical practice setting, patients who underwent radical nephrectomy showed a continuous decrease in renal function over time $[9,10]$, and most of these patients had low renal function at the time of TKI initiation. Our propensity score-matched, real-world data showed that $82.8 \%(2438 / 2943)$ patients had undergone nephrectomy and that $31.7 \%(935 / 2943)$ of patients had an eGFR of $<45$ $\mathrm{mL} / \mathrm{min} / 1.73 \mathrm{~m}^{2}$ (Table 1). 
Table 1: Patients' baseline demographics

\begin{tabular}{|c|c|c|c|c|c|c|}
\hline \multirow[b]{2}{*}{ Variables } & \multicolumn{3}{|c|}{ Before matching } & \multicolumn{3}{|c|}{ After matching } \\
\hline & $\begin{array}{c}\text { eGFR of }<45 \\
(n=935)\end{array}$ & $\begin{array}{c}\text { eGFR of } \geq 45 \\
(n=2008)\end{array}$ & $P$-value & $\begin{array}{c}\text { eGFR of }<45 \\
\quad(n=613)\end{array}$ & $\begin{array}{c}\text { eGFR of } \geq 45 \\
\quad(n=613)\end{array}$ & $P$-value \\
\hline \multicolumn{7}{|l|}{ Sex } \\
\hline Male/Female & $721(77.1) / 214(22.9)$ & $1499(74.7) / 509(25.4)$ & 0.1488 & $477(77.8) / 136(22.2)$ & $461(75.2) / 152(24.8)$ & 0.2811 \\
\hline Age, $y$ & $69.2 \pm 9.0$ & $63.9 \pm 10.8$ & $<0.0001$ & $68.9 \pm 8.5$ & $69.0 \pm 8.3$ & 0.7234 \\
\hline Weight, $\mathrm{kg}$ & $58.8 \pm 10.3$ & $59.2 \pm 12.0$ & 0.4137 & $58.9 \pm 10.3$ & $58.2 \pm 11.2$ & 0.2937 \\
\hline BMI, $\mathrm{kg} / \mathrm{m}^{2}$ & $22.4 \pm 3.2$ & $22.3 \pm 3.6$ & 0.8872 & $22.4 \pm 3.1$ & $22.4 \pm 3.5$ & 0.9257 \\
\hline $\begin{array}{l}\text { Mean eGFR, } \mathrm{mL} / \\
\mathrm{min} / 1.73 \mathrm{~m} 2\end{array}$ & $33.3 \pm 11.0$ & $63.9 \pm 17.7$ & $<0.0001$ & $33.8 \pm 10.8$ & $59.9 \pm 14.4$ & $<0.0001$ \\
\hline ECOG PS & & & 0.0918 & & & 0.4702 \\
\hline 0 & $580(62.0)$ & $1296(64.5)$ & & $382(62.3)$ & $390(63.6)$ & \\
\hline 1 & $314(33.6)$ & $602(30.0)$ & & $206(33.6)$ & $191(31.2)$ & \\
\hline$\geq 2$ & $41(4.4)$ & $110(5.5)$ & & $25(4.1)$ & $32(5.2)$ & \\
\hline TNM stage & & & 0.2917 & & & 0.6744 \\
\hline I & $8(0.9)$ & $8(0.4)$ & & $1(0.2)$ & $0(0.0)$ & \\
\hline II & $4(0.4)$ & $5(0.3)$ & & $1(0.2)$ & $2(0.3)$ & \\
\hline III & $11(1.2)$ & $31(1.5)$ & & $3(0.5)$ & $2(0.3)$ & \\
\hline IV & $910(97.3)$ & $1962(97.7)$ & & $608(99.2)$ & $609(99.4)$ & \\
\hline Unknown & $2(0.2)$ & $2(0.1)$ & & $0(0.0)$ & $0(0.0)$ & \\
\hline Prior surgery, yes/no & $801(85.7) / 134(14.3)$ & $1637(81.5) / 371(18.5)$ & 0.0055 & $577(94.1) / 36(5.9)$ & $581(94.8) / 32(5.2)$ & 0.6177 \\
\hline $\begin{array}{l}\text { Prior systemic } \\
\text { anticancer therapy }\end{array}$ & & & 0.6676 & & & 0.1459 \\
\hline IFN- $\alpha$ & $689(73.7)$ & $1483(73.9)$ & 0.9246 & $474(77.3)$ & $496(80.9)$ & 0.1221 \\
\hline IL-2 & $260(27.8)$ & $544(27.1)$ & 0.6849 & $176(28.7)$ & $174(28.4)$ & 0.8994 \\
\hline Others & $140(15.0)$ & $334(16.6)$ & 0.2540 & $102(16.6)$ & $88(14.4)$ & 0.2692 \\
\hline Primary disease $^{*}$ & & & 0.9306 & & & \\
\hline $\begin{array}{l}\text { Unresectable/ } \\
\text { metastatic }\end{array}$ & $923(98.7)$ & $1983(98.8)$ & & $613(100.0)$ & $613(100.0)$ & \\
\hline \multicolumn{7}{|l|}{$\mathrm{RCC}$} \\
\hline Others & $0(0.0)$ & $0(0.0)$ & & $0(0.0)$ & $0(0.0)$ & \\
\hline Subtype & & & 0.0687 & & & 0.2665 \\
\hline Clear cell carcinoma & $679(72.6)$ & $1457(72.6)$ & & $528(86.1)$ & $541(88.3)$ & \\
\hline $\begin{array}{l}\text { Non-clear cell } \\
\text { carcinoma }\end{array}$ & $108(11.6)$ & $183(9.1)$ & & $85(13.9)$ & $72(11.8)$ & \\
\hline \multicolumn{7}{|l|}{ Metastatic site } \\
\hline Any & $901(96.4)$ & $1950(97.1)$ & 0.2777 & $604(98.5)$ & $606(98.9)$ & 0.6148 \\
\hline Bone & $257(27.5)$ & $676(33.7)$ & 0.0008 & $180(29.4)$ & $193(31.5)$ & 0.4197 \\
\hline Brain & $45(4.8)$ & $109(5.4)$ & 0.4851 & $31(5.1)$ & $32(5.2)$ & 0.8971 \\
\hline Liver & $140(15.0)$ & $314(15.6)$ & 0.6423 & $84(13.7)$ & $78(12.7)$ & 0.6128 \\
\hline Lung/Lung only & $652(69.7) / 239(25.6)$ & $1430(71.2) / 500(24.9)$ & 0.4105 & $437(71.3) / 159(25.9)$ & $466(76.0) / 187(30.5)$ & 0.0601 \\
\hline Kidney & $76(8.1)$ & $136(6.8)$ & 0.1855 & $55(9.0)$ & $36(5.9)$ & 0.0384 \\
\hline $\begin{array}{l}\text { Other (including } \\
\text { lymph nodes) }\end{array}$ & $412(44.1)$ & $883(44.0)$ & 0.9634 & $274(44.7)$ & $245(40.0)$ & 0.0937 \\
\hline Proteinuria & $6(0.6)$ & $7(0.4)$ & 0.2631 & $4(0.7)$ & $3(0.5)$ & 0.7047 \\
\hline $\mathrm{CRP}, \mathrm{mg} / \mathrm{dL}$ & $2.8237 \pm 5.6196$ & $3.1201 \pm 4.6804$ & 0.1775 & $2.6429 \pm 5.8132$ & $2.3768 \pm 4.1017$ & 0.3546 \\
\hline
\end{tabular}




\begin{tabular}{|c|c|c|c|c|c|c|}
\hline $\begin{array}{l}\text { Favorable/ } \\
\text { intermediate/poor }\end{array}$ & $\begin{array}{l}131(14.0) / 624 \\
(66.7) / 52(5.6)\end{array}$ & $\begin{array}{l}405(20.2) / 1199 \\
(59.7) / 125(6.2)\end{array}$ & 0.0008 & $\begin{array}{c}95(15.5) / 433 \\
(70.6) / 19(3.1)\end{array}$ & $\begin{array}{l}126(20.6) / 412 \\
(67.2) / 22(3.6)\end{array}$ & 0.1122 \\
\hline \multicolumn{7}{|l|}{$\begin{array}{l}\text { Concomitant use of } \\
\text { cytokines }\end{array}$} \\
\hline Yes/no & $33(3.5) / 902(96.5)$ & $87(4.3) / 1921(95.7)$ & 0.305 & $19(3.1) / 594(96.9)$ & $30(4.9) / 583(95.1)$ & 0.1088 \\
\hline
\end{tabular}

Data are expressed as $n(\%)$ or mean \pm standard deviation.

"Including multiple choices. $†$ Patients with any line of therapy.

Abbreviations: $\mathrm{BMI}=$ body mass index; $\mathrm{CRP}=\mathrm{C}$-reactive protein; ECOG PS = Eastern Cooperative Oncology Group performance status; $\mathrm{eGFR}=$ estimated glomerular filtration rate; IFN- $\alpha=$ interferon-alpha; MSKCC $=$ Memorial Sloan Kettering Cancer Center; $\mathrm{RCC}=$ renal cell carcinoma; $\mathrm{TNM}=$ tumor, node, metastasis.

Table 2: Distribution of initial dose, median dose, dose modification, and reason for treatment discontinuation

\begin{tabular}{lccc}
\hline & \multicolumn{2}{c}{ eGFR, $\mathbf{~ m L / m i n} / \mathbf{1 . 7 3} \mathbf{~ m}^{\mathbf{2}}$} & \\
\cline { 2 - 3 } Variables & $\begin{array}{c}\mathbf{4 5} \\
(\boldsymbol{n}=\mathbf{6 1 3})\end{array}$ & $\begin{array}{c}\mathbf{2 4 5} \\
(\boldsymbol{n}=\mathbf{6 1 3})\end{array}$ & $\boldsymbol{P}$-value \\
\hline Mean starting dose, $\mathrm{mg}$ /day & $687.1 \pm 192.1$ & $726.3 \pm 159.8$ & 0.0001 \\
Median daily dose, mg/day & $484.4[388.5]$ & $481.0[415.5]$ & 0.3181 \\
Relative dose intensity, \% & $65.7 \pm 26.5$ & $67.2 \pm 26.5$ & 0.3197 \\
Median duration of treatment, mo & $6.11[10.22]$ & $6.60[9.72]$ & 0.2944 \\
Dose modification & & & \\
$\quad$ Reduction & $357(58.2)$ & $360(58.7)$ & 0.862 \\
$\quad$ Interruption & $269(43.9)$ & $263(42.9)$ & 0.7295 \\
$\quad$ Discontinuation & $429(70.0)$ & $428(69.8)$ & 0.9504 \\
Reason for discontinuation & & & \\
$\quad$ Adverse events & $264(61.5)$ & $244(57.0)$ & 0.1772 \\
$\quad$ Insufficient effect & $130(30.3)$ & $142(33.2)$ & 0.366 \\
\hline
\end{tabular}

Data are presented as mean \pm standard deviation, median [interquartile range], or $n(\%)$.

Abbreviations: $\mathrm{AE}=$ adverse event; $\mathrm{eGFR}=$ estimated glomerular filtration rate.

Several clinical studies to date have evaluated patients with renal impairment. In one study, 790 patients with metastatic RCC treated with sunitinib were divided into three groups by eGFR $(<30, \geq 60$ to $<30$, and $\geq 60$ $\mathrm{mL} / \mathrm{min} / 1.73 \mathrm{~m}^{2}$ ) and investigated for safety. However, accurate safety data were not reported. A low number of patients had an eGFR of $<30 \mathrm{~mL} / \mathrm{min} / 1.73 \mathrm{~m}^{2}(n=22)$, and there was no significant difference in safety or efficacy among the three groups [11]. In another study, 65 patients with metastatic RCC were treated with axitinib, and the risk factors for a decrease in renal function were found to be age ( $\geq 65$ years old), baseline renal function (eGFR of $<45 \mathrm{~mL} / \mathrm{min} / 1.73 \mathrm{~m}^{2}$ ), and timing of axitinib introduction ( $\geq$ third-line) [12]. Furthermore, another study showed that the risk factor for everolimus-induced acute kidney injury was pre-treatment renal dysfunction, and all patients with an eGFR of 15 to $30 \mathrm{~mL} / \mathrm{min} / 1.73 \mathrm{~m}^{2}$ $(n=2)$ developed acute kidney injury after everolimus treatment [13]. Like these clinical studies, the risk of TKIinduced renal impairment in the previous study was based on low pre-treatment renal function; however, the number of investigated patients with low renal function was limited. We divided 3255 patients into 2 groups using an eGFR cut-off of $45 \mathrm{~mL} / \mathrm{min} / 1.73 \mathrm{~m}^{2}$, which is reportedly the value at which the mortality and CVD event rates increase, and evaluated the safety of sorafenib in patients with renal impairment after propensity score matching of demographic characteristics.

With respect to the efficacy of sorafenib in patients with renal impairment, the tumour response was comparable between patients with an eGFR of $<45$ and $\geq 45 \mathrm{~mL} / \mathrm{min} / 1.73 \mathrm{~m}^{2}$ (Table 4, Figure 1). The reason for this result is that the median daily dose and duration of treatment were similar, and sorafenib treatment could be continued regardless of renal function despite the fact that the mean starting dose was significantly lower in patients with an eGFR of $<45 \mathrm{~mL} / \mathrm{min} / 1.73 \mathrm{~m}^{2}$ (Table 2). It might be considered that the lower starting dose in patients with an eGFR of $<45 \mathrm{~mL} / \mathrm{min} / 1.73 \mathrm{~m}^{2}$ was based on a concern for the safety of the patients with renal impairment. In addition, considering that treatment discontinuation due to adverse events was higher in patients with an eGFR of $<45 \mathrm{~mL} / \mathrm{min} / 1.73$ $\mathrm{m}^{2}$ (although without statistical significance) (Table 2), it is conceivable that the starting dose might have been affected by physicians' lack of familiarity with the use of sorafenib immediately after approval by the regulatory authorities as well as physicians' concern regarding 


\begin{tabular}{|c|c|c|c|c|c|c|c|}
\hline \multirow[b]{3}{*}{ Adverse event } & \multirow{3}{*}{ All } & \multirow{3}{*}{ Serious } & \multicolumn{5}{|c|}{ eGFR, $\mathrm{mL} / \mathrm{min} / 1.73 \mathrm{~m}^{2}$} \\
\hline & & & \multicolumn{2}{|c|}{$\begin{array}{c}<45 \\
(n=613)\end{array}$} & \multicolumn{2}{|c|}{$\begin{array}{c}\geq 45 \\
(n=613)\end{array}$} & \multirow[t]{2}{*}{$\begin{array}{c}P \text {-value } \\
\text { (All) }\end{array}$} \\
\hline & & & All & Serious & All & Serious & \\
\hline Any & $1195(97.5)$ & $642(52.4)$ & $604(98.5)$ & $330(53.8)$ & $591(96.4)$ & $312(50.9)$ & 0.018 \\
\hline Hand and foot skin reaction & $709(57.8)$ & $60(4.9)$ & $349(56.9)$ & $31(5.1)$ & $360(58.7)$ & $29(4.7)$ & 0.5247 \\
\hline Hypertension & $465(37.9)$ & $31(2.5)$ & $230(37.5)$ & $16(2.6)$ & $235(38.3)$ & $15(2.5)$ & 0.7685 \\
\hline Rash & $331(27.0)$ & $93(7.6)$ & $164(26.8)$ & $46(7.5)$ & $167(27.2)$ & $47(7.7)$ & 0.847 \\
\hline Lipase/amylase increase & $330(26.9)$ & $10(0.8)$ & $176(28.7)$ & $6(1.0)$ & $154(25.1)$ & $4(0.7)$ & 0.1566 \\
\hline Diarrhoea & $283(23.1)$ & $22(1.8)$ & $147(24.0)$ & $12(2.0)$ & $136(22.2)$ & $10(1.6)$ & 0.4559 \\
\hline Alopecia & $217(17.7)$ & $1(0.1)$ & $97(15.8)$ & $0(0.0)$ & $120(19.6)$ & $1(0.2)$ & 0.0852 \\
\hline Hepatic dysfunction & $215(17.5)$ & $89(7.3)$ & $110(17.9)$ & $44(7.2)$ & $105(17.1)$ & $45(7.3)$ & 0.7073 \\
\hline Cytopaenia & $167(13.6)$ & $56(4.6)$ & $102(16.6)$ & $32(5.2)$ & $65(10.6)$ & $24(3.9)$ & 0.0021 \\
\hline Decreased appetite & $127(10.4)$ & $21(1.7)$ & $66(10.8)$ & $13(2.1)$ & $61(10.0)$ & $8(1.3)$ & 0.6393 \\
\hline Bleeding & $124(10.1)$ & $84(6.9)$ & $69(11.3)$ & $49(8.0)$ & $55(9.0)$ & $35(5.7)$ & 0.1848 \\
\hline Mucositis & $110(9.0)$ & $7(0.6)$ & $55(9.0)$ & $3(0.5)$ & $55(9.0)$ & $4(0.7)$ & 1 \\
\hline Hypophosphataemia & $109(8.9)$ & $1(0.1)$ & $57(9.3)$ & $0(0.0)$ & $52(8.5)$ & $1(0.2)$ & 0.6159 \\
\hline Fever & $86(7.0)$ & $29(2.4)$ & $41(6.7)$ & $15(2.5)$ & $45(7.3)$ & $14(2.3)$ & 0.6547 \\
\hline Dysphonia & $80(6.5)$ & $0(0.0)$ & $45(7.3)$ & $0(0.0)$ & $35(5.7)$ & $0(0.0)$ & 0.2475 \\
\hline Renal failure/dysfunction & $31(2.5)$ & $12(1.0)$ & $27(4.4)$ & $9(1.5)$ & $4(0.7)$ & $3(0.5)$ & $<0.0001$ \\
\hline Proteinuria, $n(\%)$ & $21(1.7)$ & 0 & $12(2.0)$ & 0 & $9(1.5)$ & 0 & 0.5090 \\
\hline Fatigue & $17(1.4)$ & $2(0.2)$ & $6(1.0)$ & $0(0.0)$ & $11(1.8)$ & $2(0.3)$ & 0.222 \\
\hline
\end{tabular}

Data are presented as $n(\%)$.

Table 4: Tumour response to sorafenib

\begin{tabular}{lcccc}
\hline & & \multicolumn{3}{c}{ eGFR, $\mathbf{~ m L} / \mathbf{m i n} / \mathbf{1 . 7 3} \mathbf{~ m}^{\mathbf{2}}$} \\
\cline { 3 - 5 } Variables & All & $\begin{array}{c}<\mathbf{4 5} \\
(\boldsymbol{n}=\mathbf{6 1 3})\end{array}$ & $\begin{array}{c}\mathbf{2 4 5} \\
(\boldsymbol{n}=\mathbf{6 1 3})\end{array}$ & P-value \\
\hline CR, $n(\%)$ & $27(2.4)$ & $10(1.8)$ & $17(3.0)$ & \\
PR, $n(\%)$ & $286(25.3)$ & $137(24.3)$ & $149(26.4)$ & 0.4584 \\
SD, $n(\%)$ & $663(58.7)$ & $337(59.8)$ & $326(57.7)$ & \\
PD, $n(\%)$ & $148(13.1)$ & $76(13.5)$ & $72(12.7)$ & \\
NE, $n(\%)$ & $5(0.4)$ & $4(0.7)$ & $1(0.2)$ & 0.2132 \\
ORR, \% & 27.7 & 26.1 & 29.4 & 0.5350 \\
DCR, \% & 86.5 & 85.8 & 87.1 & \\
\hline
\end{tabular}

Abbreviations: $\mathrm{CR}=$ complete response; $\mathrm{DCR}=$ disease control rate; $\mathrm{eGFR}=$ estimated glomerular filtration rate; $\mathrm{NE}=$ not evaluable; $\mathrm{ORR}=$ objective response rate; $\mathrm{PD}=$ progressive disease; $\mathrm{PR}=$ partial response; $\mathrm{SD}=$ stable disease.

safety in patients with poor renal function. As shown in Table 3, the number of patients with renal failure/ dysfunction was higher among those with an eGFR of $<45 \mathrm{~mL} / \mathrm{min} / \mathrm{m}^{2}$. When fluid loss was observed due to loss of appetite or diarrhoea by disease progression and the side effects of TKI, progression to renal function deterioration became possible. Sorafenib is mainly metabolised by the liver, and $77 \%$ of the administered drug is excreted into the faeces [14]. Therefore, the pharmacodynamics of sorafenib are likely to be comparable between patients with and without renal impairment, possibly explaining why the tumour response (Table 4), PFS (Figure 1), and AEs (Table 3) were similar in both groups based on the similar serum concentration of sorafenib. However, further study is needed in this regard.

TKI-induced renal impairment may occur by several mechanisms. The first is glomerular obstruction 
by inhibition of the VEGF signalling pathway. Urine filtration is mediated through the glomerular filtration barrier, which consists of podocytes, the glomerular basement membrane, and endothelial cells [15]. VEGFproducing podocytes contribute to maintenance of glomerular function via both the podocytes themselves and endothelial cells, and the inhibition of VEGF leads to collapse of the glomerular filtration barrier, resulting in proteinuria [3]. The second mechanism is glomerular deconstruction, termed thrombotic microangiopathy. Direct endothelial dysfunction is induced by VEGF inhibition, mesangiolysis, swelling of endothelial cells and schistocytes, and thrombosis [15]. The third mechanism is based on the inhibition of the production of vasodilator such as nitric oxide and prostaglandin I 2 from endothelial cells, leading to hypertension [16]. Each TKI has a possibility of causing renal dysfunction, although there are some differences in their inhibitory specificities to VEGF. In the present study, sorafenib-induced renal dysfunction was observed in $31(2.5 \%)$ patients $(27$ [4.4\%] vs 4 [0.7\%] among those with an eGFR of $<45 v s \geq 45 \mathrm{~mL} / \mathrm{min} / 1.73$ $\mathrm{m}^{2}$, respectively; $\left.P<0.0001\right)$. Generally, renal function tends to decrease at a higher rate in patients with lower baseline renal function [17]. At the end of the present analysis, we determined that sorafenib treatment was safely conducted for at least 12 months without a decrease in renal function in most of the patients with an eGFR of $<45 \mathrm{~mL} / \mathrm{min} / 1.73 \mathrm{~m}^{2}$ (Figure 2). Moreover, the fact that the eGFR was similar between patients who did and did not discontinue sorafenib treatment (Figure 2) indicates that the treatment discontinuation was unlikely to be associated with the presence of renal impairment.

This study had three main limitations. The first is that it was a non-randomised retrospective study. Although propensity score matching balances patients' demographics and apparently shows outcomes similar to those of a randomised study, certain biases cannot be denied; for example, patients with missing data regarding the matching factors at baseline were excluded from the analysis. In addition, patients' demographics were matched using prognostic factors; however, other reported prognostic factors which were not collected at baseline could not be matched. Second, some bias might have been introduced by some physicians who may have been less familiar with the use of sorafenib because these PMS data were collected immediately after approval of sorafenib for treatment of RCC. The third limitation is the duration of the observational period, which was 12 months as required by the Pharmaceutical and Medical Devices Agency; hence, data regarding the safety and efficacy of sorafenib for $>12$ months could not be obtained.

In conclusion, in this study using propensity score matching, the demographics of patients with an eGFR of $<45$ and $\geq 45 \mathrm{~mL} / \mathrm{min} / 1.73 \mathrm{~m}^{2}$ were statistically balanced, and the safety and efficacy of sorafenib were investigated. Patients with an eGFR of $<45 \mathrm{~mL} / \mathrm{min} / 1.73 \mathrm{~m}^{2}$ tolerated sorafenib well and showed a tumour response comparable

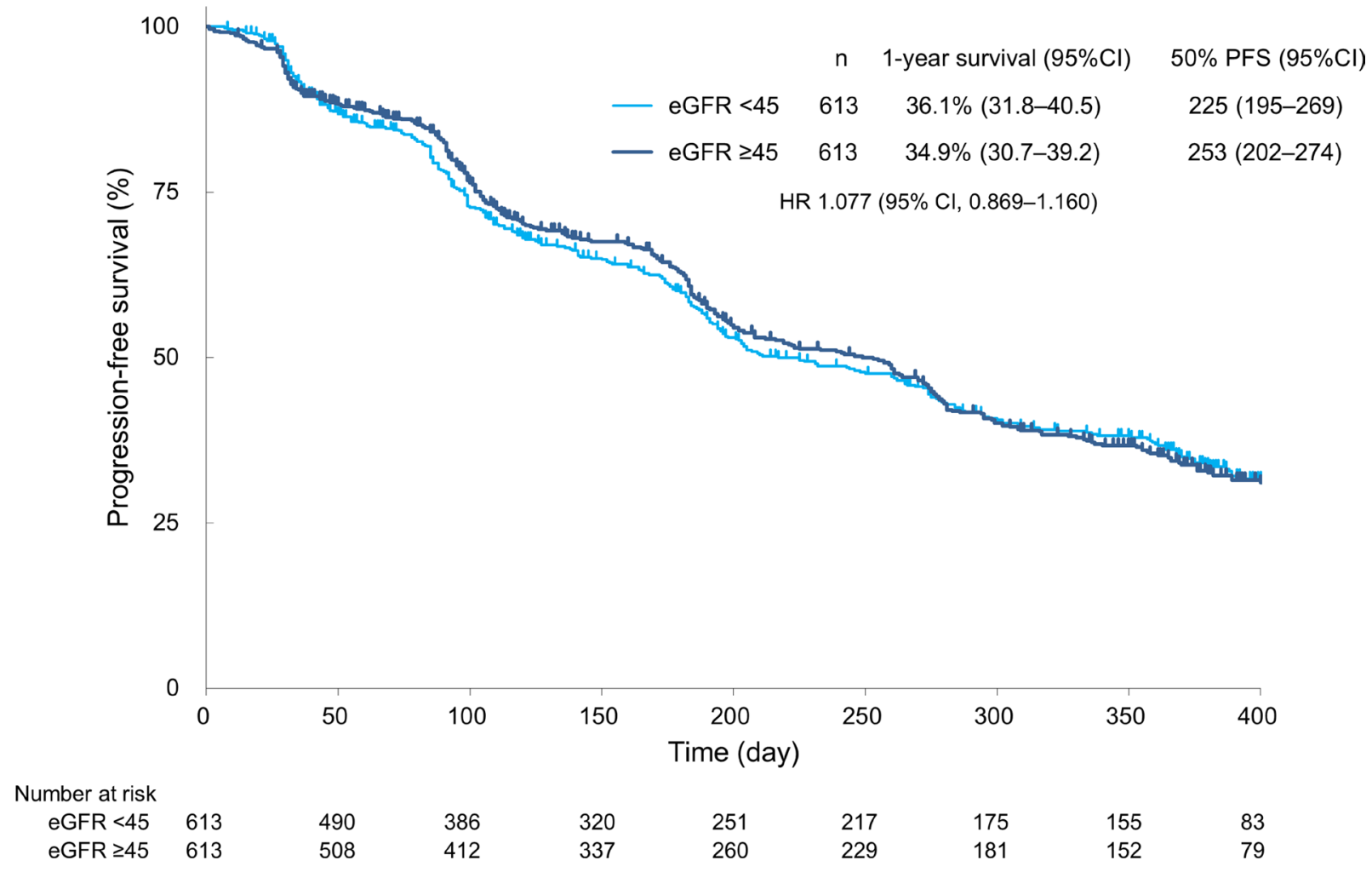

Figure 1: Progression-free survival. $\mathrm{PFS}=$ progression-free survival; $\mathrm{CI}=$ confidence interval; $\mathrm{HR}=$ hazard ratio. 
with that of patients with an eGFR of $\geq 45 \mathrm{~mL} / \mathrm{min} / 1.73 \mathrm{~m}^{2}$ (the non-renal impairment group).

\section{MATERIALS AND METHODS}

Study population. As reported in our earlier publications [18, 19], these data were derived from Japanese patients with histologically or cytologically confirmed unresectable or metastatic RCC who started sorafenib treatment from February 2008 to September 2009. Based on a requirement of the Pharmaceutical and Medical Devices Agency, these real-world data were prospectively collected from $>3,200$ patients and retrospectively analysed.

\section{Study design}

To investigate the safety and efficacy of sorafenib for patients with RCC with an eGFR of $<45 \mathrm{~mL} / \mathrm{min} / 1.73$ $\mathrm{m}^{2}$, which reportedly increases the death rate and CVD events, the background factors affecting the patients' prognosis were balanced by propensity score matching. Among 3255 patients, those with the following baseline data were selected for propensity score matching: age;
Eastern Cooperative Oncology Group performance status; tumour, node, metastasis (TNM) classification; prior surgery; prior systemic therapy; tumour histology; metastases (liver, brain, and bone); C-reactive protein level; and 1999 Memorial Sloan Kettering Cancer Center (MSKCC) risk. In total, 2,008 patients with an eGFR of $\geq 45 \mathrm{~mL} / \mathrm{min} / 1.73 \mathrm{~m}^{2}$ and 935 patients with an eGFR of $<45 \mathrm{~mL} / \mathrm{min} / 1.73 \mathrm{~m}^{2}$ were selected and matched with each other, resulting in 613 matching pairs (1226 patients). The patients' demographics, dose modifications, AEs, tumour response, PFS, and renal function (as measured by eGFR) were evaluated in these two groups.

\section{Statistical analysis}

Student's $t$-test and the Mann-Whitney $U$-test were used to evaluate parametric and non-parametric continuous variables, respectively, and the chi-square test was used for categorical data. PFS was calculated using the Kaplan-Meier method, and statistical significance was analysed by the log-rank test unless otherwise specified. SAS version 9.1 or higher (SAS Institute Inc., Cary, NC, USA) was used for all statistical analyses.

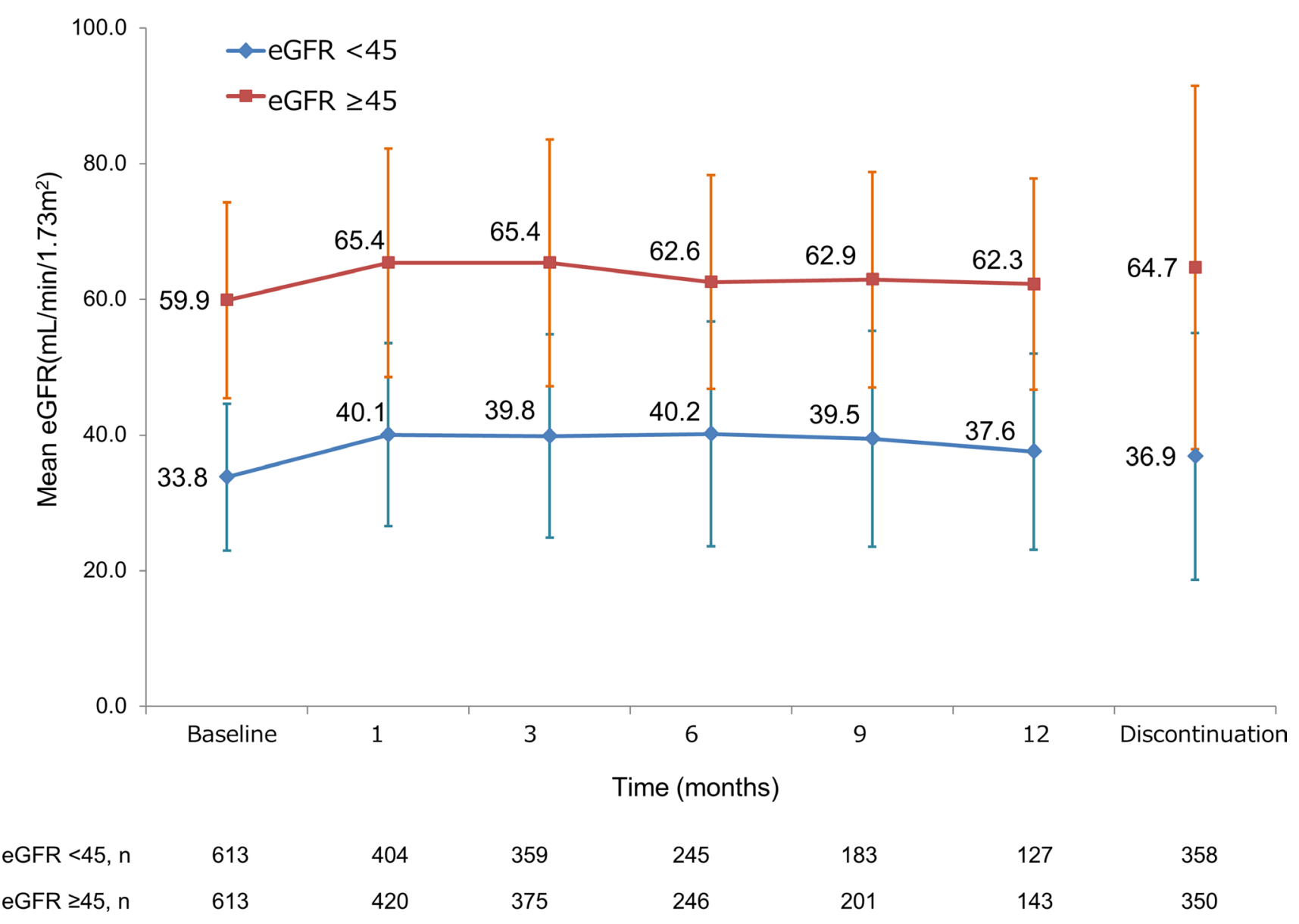

Figure 2: Change in renal function of overall patients over time according to eGFR. eGFR = estimated glomerular filtration rate. 


\section{Abbreviations}

AEs: adverse events; CKD: chronic kidney disease; CR: complete response; CVD: cardiovascular disease; eGFR: estimated glomerular filtration rate; PFS: progression-free survival; PR: partial response; RCC: renal cell carcinoma; SD: stable disease; VEGFR-TKI: vascular endothelial growth factor receptor-tyrosine kinase inhibitor.

\section{Author contributions}

KT planned the data analysis, and MO and HA gave valuable suggestions and guidance to KT. KK drafted the manuscript, which was further revised by KT. All authors read and approved the final manuscript.

\section{ACKNOWLEDGMENTS}

We thank the participating patients and staff of the study centres. Data analysis was conducted by EPS Corporation, and editorial assistance in the preparation of this manuscript was provided by ASCA Corporation; the authors retained editorial control over the content.

\section{CONFLICTS OF INTEREST}

All authors, except KK, declare no conflicts interest. $\mathrm{KK}$ is an employee of Bayer Yakuhin, Ltd.

\section{FUNDING}

The financial support of this study and the preparation of the manuscript were provided by Bayer Yakuhin, Ltd.

\section{REFERENCES}

1. Escudier B, Eisen T, Stadler WM, Szczylik C, Oudard S, Siebels M, Negrier S, Chevreau C, Solska E, Desai AA, Rolland F, Demkow T, Hutson TE, et al; TARGET Study Group. Sorafenib in advanced clear-cell renal-cell carcinoma. N Engl J Med. 2007; 356:125-134.

2. Satchell SC, Braet F. Glomerular endothelial cell fenestrations: an integral component of the glomerular filtration barrier. Am J Physiol Renal Physiol. 2009; 296:F947-F956.

3. Haraldsson B, Nyström J, Deen WM. Properties of the glomerular barrier and mechanisms of proteinuria. Physiol Rev. 2008; 88:451-487.

4. Kidney Disease: Improving Global Outcomes (KDIGO) CKD Work Group. KDIGO 2012 clinical practice guideline for the evaluation and management of chronic kidney disease. Kidney Inter. 2013; 3:1-150.
5. Go AS, Chertow GM, Fan D, McCulloch CE, Hsu CY. Chronic kidney disease and the risks of death, cardiovascular events, and hospitalization. N Engl J Med. 2004; 351:1296-1305.

6. Anavekar NS, McMurray JJ, Velazquez EJ, Solomon SD, Kober L, Rouleau JL, White HD, Nordlander R, Maggioni A, Dickstein K, Zelenkofske S, Leimberger JD, Califf RM, et al. Relation between renal dysfunction and cardiovascular outcomes after myocardial infarction. N Engl J Med. 2004; 351:1285-1295.

7. Rini BI, Escudier B, Tomczak P, Kaprin A, Szczylik C, Hutson TE, Michaelson MD, Gorbunova VA, Gore ME, Rusakov IG, Negrier S, Ou YC, Castellano D, et al. Comparative effectiveness of axitinib versus sorafenib in advanced renal cell carcinoma (AXIS): a randomised phase 3 trial. Lancet. 2011; 378:1931-1939.

8. Pfizer Japan Inc. 2015 Guide for appropriate use of axitinib [in Japanese]. Retrieved from https://pfizerpro.jp/ documents/info/inl01info.pdf.

9. Yokoyama M, Fujii Y, Iimura Y, Saito K, Koga F, Masuda H, Kawakami S, Kihara K. Longitudinal change in renal function after radical nephrectomy in Japanese patients with renal cortical tumors. J Urol. 2011; 185:2066-2071.

10. Huang WC, Levey AS, Serio AM, Snyder M, Vickers AJ, Raj GV, Scardino PT, Russo P. Chronic kidney disease after nephrectomy in patients with renal cortical tumours: a retrospective cohort study. Lancet Oncol. 2006; 7:735-740.

11. Poprach A, Bortlicek Z, Melichar B, Lakomy R, Svoboda M, Kiss I, Zemanova M, Fiala O, Kubackova K, Coufal O, Pavlik T, Dusek L, Vyzula R, et al. Efficacy of sunitinib in patients with metastatic or unresectable renal cell carcinoma and renal insufficiency. Eur J Cancer. 2015; 51:507-513.

12. Miyake H, Harada K, Imai S, Miyazaki A, Fujisawa M. Non-significant impact of proteinuria on renal function in Japanese patients with metastatic renal cell carcinoma treated with axitinib. Int J Clin Oncol. 2015; 20:796-801.

13. Ha SH, Park JH, Jang HR, Huh W, Lim HY, Kim YG, Kim DJ, Oh HY, Lee JE. Increased risk of everolimus-associated acute kidney injury in cancer patients with impaired kidney function. BMC Cancer. 2014; 14:906-912.

14. Rini BI. Sorafenib. Expert Opin Pharmacother. 2006; 7:453-461.

15. Eremina V, Jefferson JA, Kowalewska J, Hochster H, Haas M, Weisstuch J, Richardson C, Kopp JB, Kabir MG, Backx PH, Gerber HP, Ferrara N, Barisoni L, et al. VEGF inhibition and renal thrombotic microangiopathy. N Engl J Med. 2008; 358:1129-1136.

16. $\mathrm{Wu} \mathrm{S}$, Keresztes RS. Antiangiogenic agents for the treatment of nonsmall cell lung cancer: characterizing the molecular basis for serious adverse events. Cancer Invest. 2011; 29:460-471.

17. Imai E, Horio M, Yamagata K, Iseki K, Hara S, Ura N, Kiyohara Y, Makino H, Hishida A, Matsuo S. Slower decline of glomerular filtration rate in the Japanese 
general population: a longitudinal 10-year follow-up study. Hypertens Res. 2008; 31:433-441.

18. Akaza H, Oya M, Iijima M, Hyodo I, Gemma A, Itoh H, Adachi M, Okayama Y, Sunaya T, Inuyama L. A large-scale prospective registration study of the safety and efficacy of sorafenib tosylate in unresectable or metastatic renal cell carcinoma in Japan: results of over 3200 consecutive cases in post-marketing all-patient surveillance. Jpn J Clin Oncol. 2015; 45:953-962.
19. Oya M, Tatsugami K, Kabu K, Adachi M, Ito Y, Akaza H. Little Impact on Renal Function in Advanced Renal Cell Carcinoma Patients Treated with SorafenibAnalyses of Postmarketing Surveillance in Japan in over 3,200 Consecutive Cases. Gan To Kagaku Ryoho. 2016; 43:559-569. 